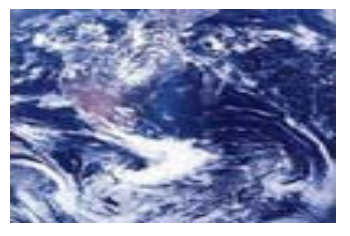

\title{
Case Study in Planning Online Interaction
}

\author{
Captain L. A. Murphy \\ Canadian Forces
}

In using the qualitative case study methodology (Merriam, 1998) an MDE candidate at Athabasca University investigated the effects of planning learning activities intended to heighten online student interaction. The investigation targeted several pivotal decisions in instructional systems design (ISD) addressed in the conversion of an existing course for online delivery. Training for Improved Performance (TIP), developed by AU (1990), was selected as the ISD model. The study sought to identify planning decisions taken during analysis, design and development processes that would foster interaction.

Wagner (1997) posited that the primary goal of interaction is a positive final outcome; not necessarily the agent upon which the educational experience was grounded. "Interaction can serve as an outcome of clearly conceptualized, well-designed, and well-developed instruction" (p. 25). She identified 12 interaction strategies:

- Participation

- Communication

- Feedback

- Elaboration

- Learner Control

- Motivation

- Negotiation

- Team Building

- Discovery

- Exploration

- Clarification

- Closure

The research problem involved the conversion of an on-campus post-secondary course to online delivery. The question was, what design decisions affected the interaction that students will ultimately experience? Eleven TIP processes were undertaken in the instructional design (ID). In this qualitative research the teacher and participant-observer came together as an ID team.

The case centred on the development and delivery of an online course entitled Planning a Marketing Strategy. Twenty one community college students took the course during the second 
semester of an automotive marketing diploma program. Furthermore, the case comprised the community college's use of an online learning management system and TIP processes. The participant-observer analyzed the interaction strategies that were employed to describe results achieved in applying TIP processes to heighten student interaction. Finally, the case study examined the heuristic of why these planning decisions led to a successful conversion of the oncampus course to online delivery.

With respect to six study questions the following conclusions were drawn:

1. Effects of planning decisions in heightening interaction for online delivery -- The participant-observer advocated that ID for online learning should rely on tenets of active learning. Interaction is an essential part of the learning strategy for any online course, including courses wrapping around a textbook. In concert with textbook readings Rowntree (1995) suggested other learning activities be incorporated in ID such as learning outcomes, overviews, discussion, contrasting viewpoints, alternative examples and feedback. Computer conferencing offered a venue for this interaction and learning activity; it provided an environment for students and teacher where they could share and build meanings as part of constructivist learning. To effectively accomplish ID, the participant-observer persuaded the teacher to follow TIP processes related to the design and development for interaction.

2. Effects attributed to use of an offline textbook and course assignment in heightening interaction for online delivery - Student-content interaction relied on the adjunct use of a textbook and course assignment. Interaction was prompted by assigned readings and some selected case studies from the textbook were used for online discussion. The course assignment permitted students further interaction in developing personal marketing plans while they employed concepts from the text, gained in mastering unit learning outcomes.

3. Interaction strategies anticipated by TIP planning decisions - In taking planning decisions, specified in the table below, the teacher considered respective interaction strategies that could be employed by students or teacher while participating in and moderating computer conferences. The activity of selecting interaction strategies was found to be almost indistinguishable from taking planning decisions.

Table 1. Summary of Planning Decisions And Interaction Strategies.

In interviewing the teacher during the study, six planning decisions envisaged certain interaction strategies.

\begin{tabular}{|l|l|}
\hline PLANNING DECISION & $\begin{array}{l}\text { INTERACTION } \\
\text { STRATEGY }\end{array}$ \\
\hline \hline \begin{tabular}{l|l|} 
Perform Instructional Analysis \\
(i.e. valid learning outcomes for weekly units)
\end{tabular} & $\begin{array}{l}\text { Learner Control } \\
\text { Communication } \\
\text { Motivation }\end{array}$ \\
\hline $\begin{array}{l}\text { Develop Performance Measures } \\
\text { (i.e. personal marketing plan and practice quizzes) }\end{array}$ & Elaboration \\
\hline
\end{tabular}




\begin{tabular}{|l|l|}
\hline $\begin{array}{l}\text { Develop A Media Mix } \\
\text { (i.e. computer conferencing with online and offline } \\
\text { instructional resources) }\end{array}$ & $\begin{array}{l}\text { Learner Control } \\
\text { Communication } \\
\text { Clarification } \\
\text { Discovery }\end{array}$ \\
\hline $\begin{array}{l}\text { Develop Forum Topics } \\
\text { (i.e. a welcoming environment and thought-provoking forum } \\
\text { questions) }\end{array}$ & $\begin{array}{l}\text { Participation } \\
\text { Communication } \\
\text { Elaboration } \\
\text { Negotiation }\end{array}$ \\
\hline $\begin{array}{l}\text { Develop Principal Components Of Instruction } \\
\text { (i.e. instructional methodology) }\end{array}$ & $\begin{array}{l}\text { Communication } \\
\text { Feedback }\end{array}$ \\
\hline $\begin{array}{l}\text { Develop Instructional Resources } \\
\text { (i.e. suggested alternative readings and website resources) }\end{array}$ & Elaboration \\
\hline
\end{tabular}

4. Help provided by the teacher so students could quickly master skills needed for interaction - The teacher provided learner support early in the online course to help students adopt skills needed for interaction. Through guidance given in online instructional materials, direction given in the discussion forum as part of learner control, and reinforcement and further guidance offered in the discussion forum as part of feedback, the teacher prompted students to complete learning tasks relevant to effective online interaction. Students needed little assistance in navigating the learning management system.

5. Teacher interaction strategies in computer conferencing and announcements - The teacher employed overwhelmingly the three interaction strategies of communication, learner control and feedback. He initiated communication in the weekly forums through a combination of approaches that included posing questions, providing additional learning resources and informing students of appropriate learning tasks. Feedback comprised the teacher's responses to individual student postings and weekly summaries of content highlighting student contributions.

6. Student interaction strategies observed in computer conferencing - Students primarily employed three interaction strategies in computer conferencing: communication, clarification and elaboration. Right from the first forum, students shared ideas and reflections relating to concepts presented in the readings. In response to the teacher's initial prompting and feedback, postings by students over eight forums comprised communication of shared ideas, with clarification of other students' contributions and elaboration beyond initial contributions. These involved relating relevant experiences and expanding ideas through other learning resources. In the participant-observer's opinion, these three strategies characterized constructivist learning. To a limited extent, students also employed interaction strategies of exploration, negotiation, exploration and participation.

To heighten interaction as part of an efficacious instructional strategy, the principal recommendation for online instructional designers and teachers falling from this case study is that certain planning decisions need to be carefully considered for possible effects on interaction. In 
this case study, planning decisions affecting interaction involved six TIP processes (identified in the table above). This study should lead to hypotheses for further research. 


\section{References}

Athabasca University. (1990). Training For improved performance series. Athabasca, Alberta.

Merriam, S. B. (1998). Qualitative research and case study applications in education. San Francisco, CA.: Jossey-Bass Publishers.

Rowntree, D. (1995). Preparing Materials for Open, Distance and Flexible Learning: An action guide for teachers and trainers. London, UK: Kogan Page.

Wagner, E. D. (1997). Interactivity: From agents to outcomes. In T. E. Cyrs (Ed.) Teaching and Learning at a Distance: What it takes to effectively design, deliver and evaluate programs: No. 71. New directions for teaching and learning. San Francisco, California: Jossey-Bass, pp. 19 - 26.

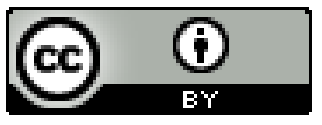

